\title{
Correlation between trends in the residential real estate market and subway development in the metropolises of the Russian Federation
}

\author{
Irina Ilyina ${ }^{1,}$, Egor Kovalsky ${ }^{1}$, Tatyana Khnikina ${ }^{1}$, and Olga Voronova $^{1}$ \\ ${ }^{1}$ Peter the Great St. Petersburg Polytechnic University, 29, Polytechnicheskaya str., Saint Petersburg, \\ Russia
}

\begin{abstract}
This paper considers connection and interdependence between construction of new subway chains and stations and development trends in the real estate market. Via comprehensive implementation of market analysis methods, together with data grouping and assessment, the study systemizes the principles required for a successful development of the urban and transport infrastructure within particular districts in SaintPetersburg and Moscow. Resulting from the conducted analysis, the authors highlighted key aspects in terms of subway construction taking into consideration its direct connection with the specifics of a given district. The interdependence between increasing prices at the real estate market and subway construction is justified.
\end{abstract}

\section{Introduction}

Moscow is the largest administrative, political and economic centre of Russia, with a population of over 10 million people. Historically, the main financial and migration flows of the country pass through the capital. After the collapse of the USSR, Moscow's attractiveness has only grown.

Moscow has replaced many union capitals, which attracts human and material flows. Head offices of regional companies were opened, together with the largest Russian organizations, representative offices, international offices are also located here. The city administration of the era of Yu. Luzhkov found an excellent way to develop the city development of a construction complex - however, due to the lack of residential and office space in the $90 \mathrm{~s}$, active development of empty urban areas and outskirts for complex development began in the capital [1,2].

Later, programs for the resettlement of panel houses with city funding were adopted. The large volume of construction of monolithic houses made it possible to resettle people who previously lived in less expensive housing. The distribution took place on the basis of administrative market mechanisms. Municipal co-financing, coupled with a high level of effective demand, have changed the urban landscape of a number of city districts. The real estate market in Moscow changes every year, for example, after the introduction of the escrow account format, at the end of 2019, the share of housing with sales under escrow

*Corresponding author: irinailina96@mail.ru 
accounts amounted to about $23 \%$ in the capital market as a whole, in business class - $19 \%$, in premium $-35 \%[3]$.

In 2019, about 5 million sq.m. of residential real estate were built in Moscow. Experts attribute this to the renovation program and the reform of shared construction. Developers were eager to complete the properties under the old financing rules.

In 2020, prices have risen more than in the hectic November 2014. A sharp decline in the volume of supply in the secondary market amid high demand, primarily for inexpensive housing, led to a record price increase. In November 2020, apartments in "old" Moscow have risen in price more than in the whole of 2019.

Cheaper housing rises in price with a higher pace than more expensive properties. So, for example, prices for apartments in old panel houses have risen in price by $6 \%$ on average, while apartments in modern monolithic buildings have grown in price by only $2.7 \%$.

At the end of November, the cost of one square meter of housing in the secondary market increased by another $4.8 \%$ and reached 200,380 rubles. The prices have grown the most - the cheapest segments: panel and brick five-story buildings, nine- and 14-story Soviet-built houses, one-room apartments, districts built up with inexpensive housing Yuzhny, Vostochny, Yugo-Vostochny, districts beyond the Moscow Ring Road [4,5].

Opening new subway stations contributes to large-scale residential real estate developments. Especially if remote areas of metropolises that are just beginning to develop are considered. At the same time, a large number of new multi-story apartment building are located in the nearest suburb with poorly developed infrastructure. Thereby, an urgent need to open a new subway station is observed, due to the fact that the population of the area is growing (which is explained by low cost of apartments) and ground transport can no longer ensure mobility for all citizens.

\section{Materials and methods}

This paper mainly applies analytical methods such as description, cause and effect analysis and grouping. By using the given methods, the authors were able to efficiently analyse current condition of the real estate market in Saint-Petersburg and Moscow, thereby distinguishing the relevant issue and trends in the construction market. The summarizing method was also implemented throughout the study in order to observe opinions of experienced practitioners of the study area under analysis.

\section{Results}

It is difficult to ignore the obvious relationship between construction and opening of new subway stations, which significantly improves the transport infrastructure of the area, and the growing housing prices. One of the most illustrative examples is the Shushary district in St. Petersburg. Mass construction of Shushary began in 2004-2005. Many estate developers found the area extremely appealing due to its close location to the Ring Road, airport, and the Moscow Highway - the main highway between Moscow and Saint-Petersburg. As a result, in just a few years, the village of Shushary turned into a promising area of St. Petersburg, with a huge number of high-rise new buildings and economy-class apartments, though still with a low-developed infrastructure. Growing demand for housing in the area and sharp increase in the population contributed to the urgent opening of the Shushary metro station in 2019. Consequently, in this case, an inverse correlation is observed. First, the district was developed together with the residential real estate, followed by opening of the subway station $[6,7]$. 
It should be noted that the scheme of subway development of St. Petersburg for the next few years involves opening of new stations in those areas where a large number of residents of the city and dense development of residential buildings occurs. Significantly enough, the same trend is observed in Moscow.

In order to representatively track the connection between rising real estate prices and opening of new subway stations, the paper considers the Ramenki district in Moscow. Prices in this area are at the level of the most expensive locations, such as Khamovniki, Zamoskvorechye and Presnensky district. Pricing is currently explained by convenient location, modern infrastructure and high transport accessibility, which was not typical of the district before.

Convenience of the given location for potential development is discussed below.

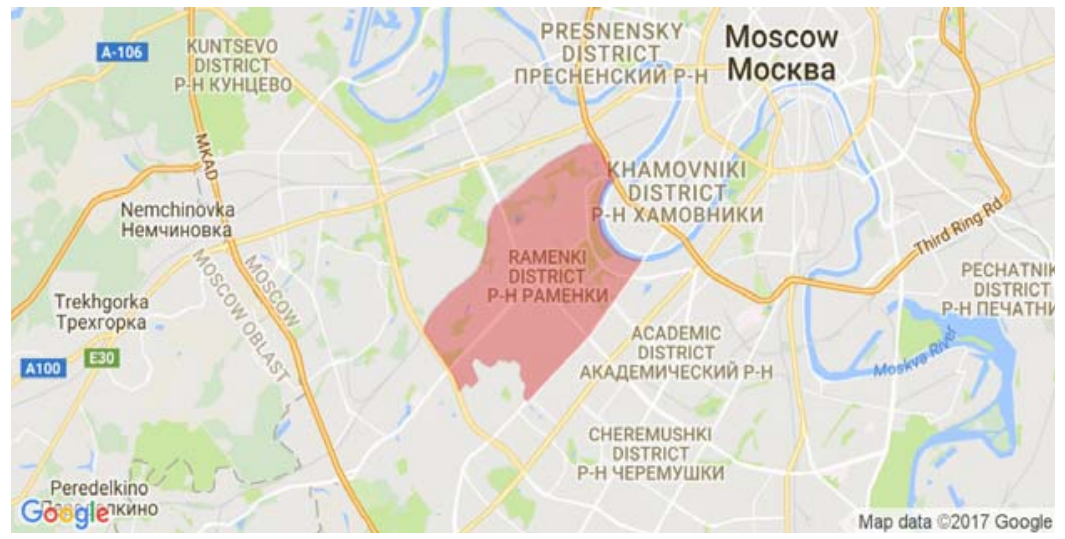

Fig. 1. Location of the Ramenki district, Moscow.

It is crucial to pay attention to the fact that, being located between the third transport ring and the MKAD, as shown in Figure 1, there are no industrial enterprises in the district. It was in this area where one of the first elite residential complexes in Moscow was built. The embassy quarter, where embassy staff live, is also located here.

The growth in the population number provides an increase in demand for real estate, the popularization of the area, and, consequently, an increase in the value of real estate. In $77 \%$ of cases, a change in the population of the district leads to a change in the cost of housing in the primary market in the Ramenki district.

Currently, the average price level for apartments in the Ramenka is 265,455 rubles per sq.m. The district ranks 13th out of 86 in this indicator. At the same time, the indicator is higher than the average Moscow level of apartment prices by $32.5 \%$. In the Ramenka district, the housing security index per inhabitant is $40 \%$ higher than the average in the capital. There are about 30 square meters of residential real estate per one resident of the district. The new construction projects are dominated by multi-storey buildings of the business class. In the area of Dovzhenko Street, Mosfilmovskaya Street, on Michurinsky Avenue, Soviet and Russian filmmakers received housing. There are a number of prestigious schools in Ramenki. Moscow State University is located in the district together with the Russian Academy of Foreign Trade.

However, the main drawback of Ramenok was the insufficient number of subway stations in the south-western part of the district. Previously, only two stations "Vorobyovy Gory" and "Universitet" operated in the entire district. However, in 2017, "Lomonosovsky Prospekt", "Ramenki" and "Michurinsky Prospekt" were opened here, which certainly affected the pace of further development and the growth of prices for residential real estate.

In the secondary housing market in Ramenki, more than 2,500 objects are now being sold, from 7.5 million to 1.4 billion rubles. The volume of proposals for new buildings: 
more than 1,400 objects, at a cost of 8 million to 1.4 billion rubles per apartment. Monolithic and panel houses account for $37 \%$ of the total supply in the district, $19 \%$ - for brick buildings, $5 \%$ of the apartments for sale are in block houses, $2 \%$ - in "stalinki". The smallest share in the volume of supply amounts to economy class objects $-22 \%, 39 \%$ each is accounted for by comfort and premium class apartments.

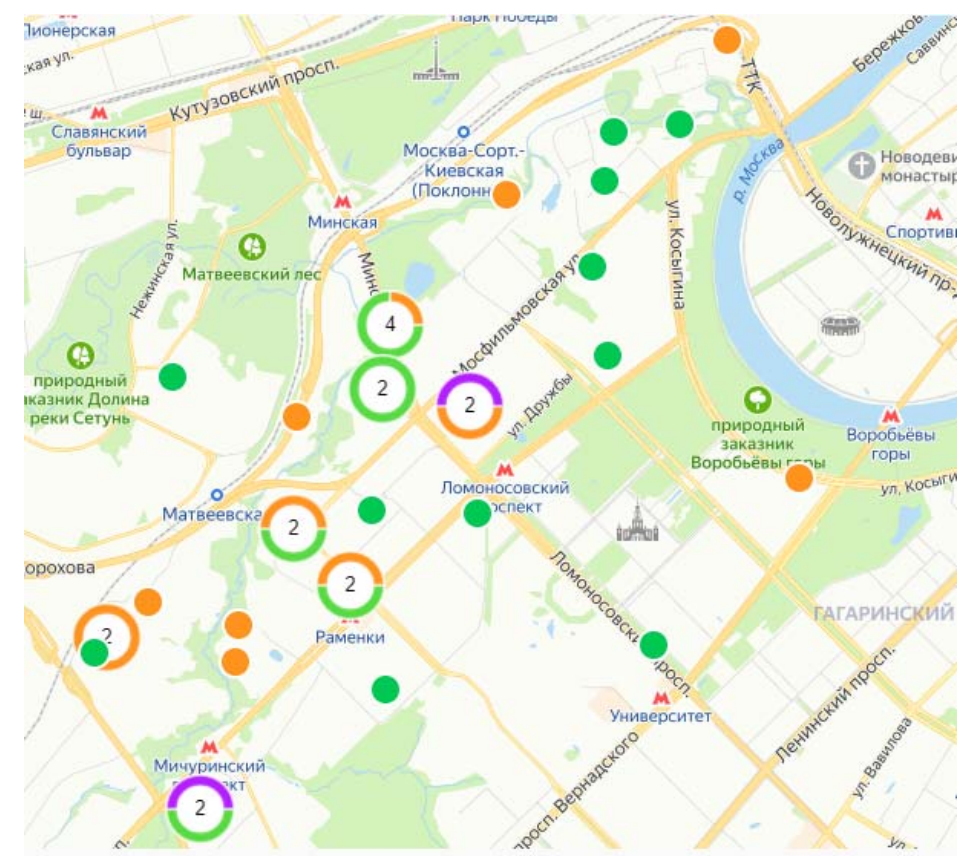

Fig. 2. New residential complexes in the Ramenka district, December 2020.

Figure 2 above considers the quantity of projects that are currently being completed or ready. At the moment, in terms of supply, this district ranks sixth among other districts of Moscow (after Presnensky, Khamovniki, Tver, Basmanny and Maryino).

Table 1 given below shows examples of new construction projects and the minimum prices for an apartment in a particular residential complex.

Table 1. Prices for new buildings in the Ramenka district.

\begin{tabular}{|c|c|c|}
\hline Project & Comission & Price \\
\hline Hide & 1 room apartment, 2023 & from 17,133,715 rubles. \\
\hline Krilya & 1 room apartment, 2021 & from 11,485,670 rubles. \\
\hline Nebo & 4 room apartment, 2020 & from 10,243,291 rubles. \\
\hline Nastoyashee & 2 room apartment, 2022 & from 12,768,468 rubles. \\
\hline Sobitiye & 1 room apartment, 2021 & from 15,413,200 rubles. \\
\hline & & \\
\hline Dolina Setun & on comission & from 58,181,767 rubles. \\
\hline Ogni & 4 room apartment, 2021 & from 9,174,800 rubles. \\
\hline West Garden & 2 room apartment, 2023 & from 10,648,582 rubles. \\
\hline Mosfilmovsky & on comission & from 20,300,000 rubles. \\
\hline Schastye in Lomonosovsky & on comission & from 27,287,800 rubles. \\
\hline
\end{tabular}

According to the table, a studio apartment in one of the new residential complexes of the Ramenki district of Moscow will cost 2-3 million more than the cheapest lot in the secondary housing market of the same area, which indicates the increasing dynamics of 
price growth for new residential real estate after the introduced infrastructure changes, including transport $[8,9]$.

Development of districts in the city center shows that good quality premium houses, in which the appropriate price level is maintained, enter the market only when the environment is largely formed (similar residential complex already exists) and when the conditions for a comfortable living are provided. Despite the advantages of the Ramenki district, the market for premium new buildings outside the TTK is still making its first steps. Subsequently, it is considerably difficult to compare it with a similar offer inside the Sadovoye Ringroad.

\section{Discussion}

It is particularly obvious that it makes no sense to open new subway stations in the locations where very few people live. However, when purchasing housing, transport accessibility has been and remains one of the key factors $[10,11]$.

Major factors that are taken into account when planning new subway stations are presented below:

1. Remote location of the district. These areas are often characterized by difficulties with the transport infrastructure.

2. Quantity of residential buildings and people living in them. At the same time, it is necessary to take into account the level of security of the population. For example, in the Moscow region and the Leningrad region, there are several fairly remote areas, but the housing stock there consists of expensive cottages and townhouses, and people prefer to travel to the city by car. In this case, subway construction will be unjustified.

3. Quantity of offices and business centres. The city (or the outskirts) often have an industrial zone, with factories and plants, where almost no one lives, but where people come to work every day. In such a situation, it is necessary to open new stations, as it will significantly simplify the lives of many citizens.

4. Another important factor is severe traffic. Subway station can be planned there, in order to relieve the ground transport routes and reduce the traffic-related stress.

It is worth mentioning that when a new metro station is opened in a promising area, the cost per square meter of housing sharply increases by $20-30 \%$, both in new and secondary buildings. Buyers of apartments should take into account that they always have two options: buy cheaper, but far from subway, or overpay, but it is convenient and fast to get anywhere in the city [12].

Based on the Yandex.Realestate for 2019, the dynamics of prices for residential real estate related to the opening of new metro stations is presented below.

Table 2. Housing costs dynamics depending on the opening of new subway stations.

\begin{tabular}{|c|c|c|c|}
\hline Station name & $\begin{array}{c}\text { Opening } \\
\text { date }\end{array}$ & $\begin{array}{c}\text { Growth of housing prices } \\
\text { in new buildings } \\
\mathbf{2 0 1 8 - 2 0 1 9}\end{array}$ & $\begin{array}{c}\text { Growth of housing prices } \\
\text { in the secondary market } \\
\mathbf{2 0 1 8 - 2 0 1 9}\end{array}$ \\
\hline "Filatov lug" & 20.06 .2020 & $20 \%$ & $18.68 \%$ \\
\hline "Prokshino" & 20.06 .2020 & $0.84 \%$ & $30.83 \%$ \\
\hline "Ol'khovaya" & 20.06 .2020 & $31.15 \%$ & $21.13 \%$ \\
\hline "Kommunarka" & 20.06 .2020 & $20.93 \%$ & $23.36 \%$ \\
\hline $\begin{array}{c}\text { Average } \\
\text { indicator }\end{array}$ & & $20 \%$ & $27.03 \%$ \\
\hline
\end{tabular}

The data is given only for a small part of the opened stations, but it is possible to say that for the rest of the examples the result will not differ much. However, sometimes you can see some differences in the increase in real estate prices in the primary and secondary 
markets $[13,14]$. The fact is that developers, analyzing the existing territory, pay attention to both the immediate and long-term prospects of the district. Consequently, if there is reliable information that a new metro station is planned to be opened in the immediate vicinity of the proposed residential complex, then the increased cost per square meter is initially included in the project.

Thus, despite the transport "abandonment" of the territory at the moment, the shareholders make investments for the most part in the very prospects of the project. People are willing to overpay for comfort and convenience, but sometimes a drastic price increase becomes inappropriate. For example, if we are talking about dense development of economy class high-rise buildings in a remote area of the city. For residents of such houses, the nearest metro station will be the only highway that connects them to the "rest of the world" [15].

To turn a real necessity into a luxury in this case will be, at least, disrespectful to the residents of this area. As a rule, in such remote places, there are also problems observed with ground transport and increased transport fares.

\section{Conclusions}

Expansion of subway network has a significant impact on the cost of housing in the surrounding districts. At the same time, the cost per square meter changes gradually, starting with the announcement of the opening of a new station, and ending with the sale of ready-made apartments in new buildings.

Opening of new subway stations and development of the residential real estate market are closely interrelated. Thereby, if the station opens in a new district, where there are already quite a lot of residential buildings, there is a powerful impetus for the development of this very district. Infrastructure is developing, retail is increasing, and in general, the attractiveness of housing in such districts is increasing.

However, if there is a station opening in the city centre, where there is already an established system and many old houses, this will affect the cost of housing slightly. Such stations are mainly built to connect parallel metro lines and make movement of passengers more convenient.

The key point is that no large-scale development of new economy class and comfort class buildings can be successfully implemented without new subway stations due to the fact that this will be inconvenient for residents and unprofitable for developers. Moreover, it is obvious that no subway station will open in the location characterized by no potential and plans for building new houses or business centres.

\section{References}

1. S. Maksimov, Real Estate Economics (1999)

2. T. Ksenofontova, V. Demirova et al.6 Eur. Leg. J. 2, 429-431 (2020)

3. J. Friedman, N. Ordway, Delo (1997)

4. A. Tregubova, V. Zasenko, O. Ilina et al., Mon. LEMA 152 (2014)

5. N. Zhuravlev, Soc.-econ. phenomena and processes 1, 68-71 (2012)

6. A. Kazakov, Bul. of the Udmurt University 2, 47-52 (2008)

7. N. Breslavtseva, S. Ryabokon, Engineering Bul. of the Don 15, 526-539 (2011)

8. N. Alekseeva, Real est. transactions (2011)

9. S. Pupentsova, Man. Real Estate (2010) 
10. A. Asaul, Real Estate Economics t.b. for un-ties (2016)

11. V. Litovchenko, Cadastre, expertise and evaluation of real estate objects (2015)

12. A. Smolentsev, Mod. asp. of the econ. 6, 79-84 (2015)

13. A. Cheremisin, Act. prob. of mod. sc., tech. and educ. 2, 221-222 (2012)

14. L. Gochiyaeva Man. of econ. sys. J. 11, 16 (2012)

15. M. Makhotlova, K. Tsvetkova, Mod. sc. res. and dev. 3, 791-793 (2018) 